\title{
JUURNAL.RU
}

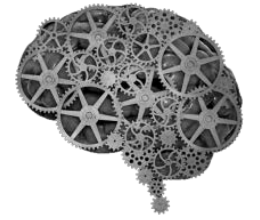

COMPANY GROUP "INTELLEKT"

Котанджян В.А. Саратовский национальный исследовательский государственный университет имени Н.Г. Чернышевского Саратов, Россия

doi: 10.18411/lj2016-5-1-09

\section{Развитие новой доминанты обеспечения предпринимательской деятельности}

Рассматривая предпринимательскую деятельность, нельзя не отметить появление нового явления, такого как виртуальный бизнес.

Понятие «виртуальная организация» имеет несколько толкований. Одни под виртуальной концепцией подразумевают не более чем способность компаний использовать информационные технологии для эффективной совместной работы людей, разбросанных по разным местам и даже разным континентам. Для других это понятие имеет более широкое значение и соответствует аморфной организации, состоящей из проектных команд, которые формируются с конкретной целью и могут быть мгновенно распущены [1]. Новые организации уже не встраиваются в модель строгой иерархической пирамиды, с вершины которой всезнающий и всевидящий генеральный директор обозревает корпоративные владения. Воплощением организации становятся совершенно иные формы и образы.

Теперь организацию описывают в терминах теории хаоса. Статья в журнале «California Management Review» описывает организацию будущего как «динамически стабильную», «способную обслужить самый широкий ряд потребителей и удовлетворить непостоянный спрос на товары (динамика), опираясь на долгосрочные процессы и коллективное знание организации (стабильность)». Организация обрела новый облик: теперь она напоминает не столько механизм, хорошо отлаженную машину, сколько неуловимую и изменчивую амебу. Американские авторы Уильям Давидоу и Майкл Малоун пишут об организации будущего: «Внешнему наблюдателю может показаться, что это структура с очень смутными очертаниями, проницаемыми и постоянно меняющимися поверхностями соприкосновения с другими компаниями, поставщиками и потребителями. Изнутри фирма выглядит не менее 
аморфной, с постоянно перестраивающимися, в зависимости от обстоятельств, традиционными офисами, отделами и операционными отделениями». Конечным результатом этого является виртуальная организация.

Утверждается, что применение информационных технологий устраняет необходимость пребывания в офисе тех сотрудников, которые могут работать удаленно - из дома или других офисов по всему миру, подключаясь к виртуальному сообществу, поддерживаемому технологиями. Виртуальная организация представляет собой неуловимое, изменчивое сочетание технологий, опыта и сетей. Таким образом, компании избавляются от громоздких зданий своих штаб-квартир, дорогостоящего «кирпича и бетона» обычного бизнеса. Сотрудники могут работать дома или, при необходимости, в офисах-спутниках. Общаясь при помощи компьютерных сетей, модемов и электронной почты, работники освобождаются от обременительных поездок на работу и ежедневной офисной рутины. Виртуальная организация повышает уровень жизни и прибыли одновременно. Так виртуальность создает благоприятные условия для бизнеса [2, с. 25-27].

Другие сторонники виртуальной организации считают, что это только начало. Ряд компаний пришли к выводу о том, что виртуальная работа позволяет полностью отказаться от традиционной структуры организации. Они отстаивают модель организации, объединяющей людей или компании в работе над общим проектом; при этом виртуальная организация или команда распускается сразу по завершении проекта.

Виртуальные организации, при всем их разнообразии, обладают одним общим свойством: они исходят из предпосылки, что информационные технологии позволяют людям в разных географических точках работать вместе, несмотря на расстояния. Их способность общаться и обмениваться информацией приводит к коренному изменению модели принятия решений [3, с. 173-175]: теперь уже нет необходимости в координации из центра. О виртуальной организации накоплено немало знаний, и она рассматривается как логическое продолжение технологий. Но безжалостная логика не может скрыть от нас тот факт, что виртуальная организация пока примечательна своим отсутствием. Существуют организации, которые потребители считают виртуальными, но в реальности они таковыми не являются. Телефонный банкинг кажется более виртуальным, чем банк за углом, но даже у компаний, предоставляющих банковские услуги по телефону, есть обычное офисное здание. Компании могут перебраться в более дешевые помещения, но они по-прежнему предпочитают вкладывать в надежный «бетон».

Следует отметить, что процессы виртуализации оказывают существенное влияние на развитие предпринимательской деятельности, а именно: изменяют структуру внутри данного 
вида деятельности, устанавливая новые правила взаимодействия; создают конкурентные преимущества, предоставляя институциональным акторам, занимающимся ею, новые возможности для развития; порождают новые виды бизнеса и механизмы, их регулирующие.

\section{Литература:}

1. Сердюк В.А. Сердюк В.А. От виртуальной реальности к виртуальному правительству: миф или реальность? Менеджмент в России и за рубежом №2, 2002.

2. Устинова Н.Г. Виртуализация инновационной инфраструктуры. В книге: Научная мысль и современный опыт в решении системных проблем развития. //Сборник научных трудов по итогам научно-исследовательской работы ученых Саратовского социально-экономического института (филиала) ФГБОУ ВПО «РЭУ им. Г.В. Плеханова» по итогам 2013 г. Н.С. Яшин (отв. редактор). 2014. С. 25-27.

3. Ромашкин Т.В. Кластерная активность российского общества. В книге: Экономические, институциональные и технологические проблемы повышения конкурентоспособности национальной экономики в условиях внешних вызовов Материалы международной научно-практической конференции. Редакционная коллегия: Н.С. Яшин, Т.С. Мельникова, С.Ю. Седова, А.А. Сытник. 2015. С. 173-175. 